\title{
Knowledge, attitudes and decision-making in Czech women with atypical results of prenatal screening tests for the most common chromosomal and morphological congenital defects in the fetus: Selected questionnaire results
}

\author{
Vladana Skutilova ${ }^{\mathrm{a}, \mathrm{b}}$
}

\begin{abstract}
Aims. The primary aim was to investigate variables affecting compliance in pregnant women recommended for genetic consultation for abnormal screening test results, family predisposition or medical history. Our main focus was on a women's knowledge of particular screening tests, their initial feelings and changes in these feeling with time, as well as variables relevant to further decision making.

Methods. We used an anonymous questionnaire based on previous qualitative research. The questions were formulated by a medical geneticist, and the questionnaires were distributed prior to prenatal screening tests performed by doctors or trained nurses. The research cohort consisted of 271 women aged 16-42 years. Six hypotheses were tested using the statistical programme STATISTICA; significance levels were set to $P<0.05$.

Results. The questionnaire results showed insufficient knowledge. The women were confused about invasive, screening and ultrasound tests. Genetic test recommendation was largely associated with stress in these patients. Between recommendation and consultation, the women mostly looked for support from their partners. There was a surprisingly low percentage of women who looked for help from their medical specialists and a surprisingly high percentage of those who did not seek any help at all.
\end{abstract}

Conclusion. Women's distress can be reduced if the information about recommended genetic consultation is conveyed correctly and this can also help them make the right informed decision about their future course of action.

Key words: prenatal counselling, screening programmes, genetic tests, invasive tests, amniocentesis, karyotyping, stress, anxiety, fear, questionnaire

Received: November 5, 2012; Accepted with revision: June 6, 2013; Available online: June 14, 2013 http://dx.doi.org/10.5507/bp.2013.046

${ }^{a}$ Department of Medical Genetics, University Hospital Hradec Kralove, Hradec Kralove, Czech Republic ${ }^{b}$ Department of Medical Genetics and Fetal Medicine, Faculty of Medicine and Dentistry, Palacky University Olomouc and University Hospital Olomouc, Olomouc

e-mail: vladana.krivkova@seznam.cz

\section{INTRODUCTION}

In the past decade, there has been a rise in publications of studies investigating the knowledge of women about screening tests for Down syndrome and the most common chromosomal and morphological congenital defects in the fetus, particularly as there is a yearly increase in such incidents. The majority of studies point to inadequate awareness of women who are offered individual methods of screening ${ }^{1-5}$. These authors concentrated particularly on stress, coping strategies and provision of support for pregnant women in connection with invasive screening tests ${ }^{6-10}$. More studies are discussed below.

Among Czech authors who have studied the problem of social and psychological support in pregnancy are Doudová and Calda ${ }^{11}$, Peňázová ${ }^{12}$ or Vágnerová ${ }^{13}$ in the nineties. More recent Czech studies concentrate more on the perinatal period ${ }^{14,15}$. Tyrlík et al. ${ }^{16}$ published a study on aspects of the positive enjoyment of pregnancy.

Our aim was to map the level of knowledge of screening tests that were recommended to pregnant women by their practitioners. Additionally, we concentrated on the decision making process in women with abnormal screen- ing test results, of older age, with family or medical predisposition, with regard to their feelings and the effects of time on these feelings about invasive examinations.

\section{MATERIALS AND METHODS}

The study was carried out at the Department of Medical Genetics, University Hospital, Hradec Kralove and in the genetic surgery of Litomyšl Hospital. Our investigation took place between September 2011 and March 2012. The study was part of a larger research that mapped the psychosocial aspects and their impact on patient compliance during prenatal examinations. We focused on the combined screening of first trimester ${ }^{17-22}$, biochemical screening of second trimester ${ }^{21,22}$, a genetic consultation associated with atypical results of any screening tests and ultrasound examination at $20^{\text {th }}$ to $22^{\text {nd }}$ week $^{22}$.

This study followed previous qualitative investigation which enabled us to set areas of interest. A preliminary cohort of 50 women was used to validate individual questions prior to starting this study ${ }^{23}$. Based on the findings of the qualitative survey, a questionnaire was devised for 
quantitative research. This procedure was chosen because the initial use of a qualitative approach allowed us to identify the variables that could be neglected using only a quantitative approach. The questions were created by a medical geneticist.

The questionnaires contained a combination of different types of questions. Demographical data were extracted from multiple choice questions, and open questions mapped the knowledge of women with respect to the individual tests. The level of knowledge of individual screening tests was assessed by a Likert scale.

A total of 300 respondents were reached. The return rate was 281 respondents, 7 questionnaires were inadequately completed. The process therefore used 274 questionnaires, i.e. $91.3 \%$. The questionnaire was distributed to women before genetic consultations, who have been recommended for consideration for amniocentesis with subsequent fetal karyotyping. Although current diagnostic possibilities shift to the earlier stages of pregnancy and the number of chorionic biopsy is growing, amniocentesis is so far the most common invasive prenatal examination.

Instructions on how to fill in the questionnaires were provided by doctors and trained nurses. The study was anonymous and required the consent of informed patients' as well as the consent of legal guardians for patients who were younger than 18 years.

Women aged 35-39 years formed the largest group (37.6\%), followed by women aged $30-34$ years $(27.3 \%)$, then women aged $25-29$ years (17\%). Older women (aged 40 years plus; $4.8 \%$ ) and very young women ( $15-19$ years; $3 \%$ ) were least represented.

The majority of women (39.1\%) completed vocational qualifications at colleges of higher education, $32.8 \%$ of women obtained an apprenticeship, $23.6 \%$ of patients completed university education and $4.4 \%$ of women completed secondary school. Nearly 70\% (67.9\%) of women identified themselves as people of faith/believers, $57.6 \%$ of women spent less than an hour browsing the internet, $30.3 \%$ of women spent $1-2 \mathrm{~h}$ per day on the internet and $12.3 \%$ of women browsed the internet for more than $2 \mathrm{~h}$ a day. Pregnancies were spontaneous in the majority of cases $(94 \%), 6 \%$ of women had conceived using methods of assisted reproduction. Additionally, the majority of pregnancies were planned $(80.1 \%)$. More than one quarter of all patients $(27.3 \%)$ were primigravidae. Of the remaining multigravidae $33.9 \%$ were pregnant for the second time, $18.5 \%$ were pregnant for the third time, others were represented in small numbers. $14.4 \%$ of women had a history of one spontaneous abortion, $5.5 \%$ had two miscarriages and $3.7 \%$ women had miscarried 3 times or more, $6.3 \%$ of patients had a previous diagnosis of congenital anomaly of the fetus/child.

Nearly half of all patients (48.3\%) were referred for a genetic consultation on the basis of an abnormal biochemical screening test in the second trimester, $14.4 \%$ on the basis of an abnormal combined first trimester screening test, $4.1 \%$ on the basis of an abnormal result of an integrated screening test, $31.7 \%$ of the patients were referred for an amniocentesis based on their older age and $1.5 \%$ of women due to a family history of medical predisposition.
We set 5 hypotheses to work with in the future: H1: Knowing more information concerning individual tests reassures pregnant patients.

$\mathrm{H} 2$ : Women referred for genetic consultation following an abnormal first trimester screening test result are more anxious and show more negative feelings compared to women referred on the basis of an abnormal second trimester biochemical screening test, or due to older age.

H3: There is a correlation between previous spontaneous abortion(s) and negative feelings about the amniocentesis.

H4: Women who discussed abnormal screening test results with their gynaecologist were less anxious than those seeking information on the internet.

H5: There is a dependence between the decision regarding going ahead with the amniocentesis and screening test results.

\section{Data analysis}

Descriptive statistical methods were chosen to characterise the cohort (age, sex, education etc.). The STATISTICA programme was then used to test our hypotheses, using Chi-square methods with Yates correction, t-test and Mann-Whitney. Levels of significance were set at $P<0.05$.

\section{RESULTS}

We investigated women's knowledge of amniocentesis using open questions to which women had to provide an answer.

The majority of women $(82.3 \%)$ had attended a genetic consultation during a previous pregnancy, $17.7 \%$ of women were referred for a consultation for the first time. Nearly $90 \%$ (86.7\%) of patients claimed to have sufficient information about amniocentesis before their genetic consultation. Therefore, we investigated what women associate with the term amniocentesis. Responses are recorded in Table 1. Sources of information are recorded in Table 2, in which the number of responses are given (as opposed to percentages) as the question offered multiple answers.

The study also investigated emotions and their dynamics in women referred for genetic consultation. This was also multiple choice. Predominant emotions were negative; 152 women reported fear, 76 anxiety, 55 sadness, 27 hopelessness and 14 women reported anger. In contrast, only 71 women were glad to have been offered the consultation, 45 women were not surprised and 36 patients did not have any unusual feelings.

Women are informed about abnormal screening test results by their gynaecologists and they were then advised to book an appointment for a genetic consultation. In the Department of Medical Genetics at the University Hospital in Hradec Kralové, the consultation usually takes 
Table 1. Possibilities/purpose of amniocentesis and karyotyping.

\begin{tabular}{lc}
\hline Response & Percentage \\
\hline I don't know & 31.7 \\
Down syndrome & 19.9 \\
$\begin{array}{l}\text { Down syndrome and chromosomal } \\
\text { anomalies }\end{array}$ & 14.8 \\
Genetic anomalies & 12.2 \\
Cleft anomalies & 11.8 \\
$\begin{array}{l}\text { Everything } \\
\text { Other answers } \\
\text { (represented in small numbers) }\end{array}$ & 3 \\
\hline
\end{tabular}

Table 2. Source of information.

\begin{tabular}{lc}
\hline Source of information & Answers \\
\hline Internet & 121 \\
Gynaecologist & 115 \\
Family & 72 \\
Friends & 63 \\
Specialised literature & 43 \\
Specialist & 35 \\
\hline
\end{tabular}

place within a week of being informed of abnormal test results. However, some women take longer. During this interim period, no change in emotions was reported by $60.9 \%$ women, there was emotional improvement in $27.7 \%$ and heightened emotional state in $11.4 \%$ of patients.

The majority of patients looked for help from their partners (178), 84 women turned to their parents, 35 to their friends, 19 to wider family and only 15 women turned to their gynaecologists. Interestingly, 69 women did not seek any help or support.

Our study also mapped reasons, which influence the decision making processes as to whether to undergo further invasive tests. Reasons for undergoing invasive tests are summarised in Table 3 and those against in Table 4.

Table 3. Reasons for undergoing invasive tests.

\begin{tabular}{lc}
\hline Reason for undergoing amniocentesis & $\begin{array}{c}\text { Percentage of } \\
\text { answers }\end{array}$ \\
\hline To make sure fetus/baby is healthy & 74.8 \\
Peace of mind & 9.4 \\
Woman does not want a disabled child & 6.9 \\
Medical recommendation & 5.4 \\
Older maternal age & 2.5 \\
Family or medical predisposition & 1 \\
\hline
\end{tabular}

Table 4. Reasons against undergoing invasive tests.

\begin{tabular}{lc}
\hline $\begin{array}{l}\text { Reasons against undergoing invasive } \\
\text { tests }\end{array}$ & $\begin{array}{r}\text { Percentage } \\
\text { of answers }\end{array}$ \\
\hline $\begin{array}{l}\text { Risk or complications associated with } \\
\text { the test }\end{array}$ & 46.4 \\
$\begin{array}{l}\text { Low reliability of the biochemical } \\
\text { screening test which was abnormal }\end{array}$ & 17.4 \\
$\begin{array}{l}\text { Don't know, don't want to, will wait } \\
\text { for geneticist recommendation and } \\
\text { then make up my mind }\end{array}$ & 14.5 \\
$\begin{array}{l}\text { No reason given } \\
\text { I want a baby as it is }\end{array}$ & 11.6 \\
$\begin{array}{l}\text { Ultrasound examination will replace } \\
\text { amniocentesis }\end{array}$ & 8.7 \\
\end{tabular}

Based on our clinical experience, we proposed that the possibilities of screening and invasive prenatal tests are often confused in the layman's view. This proposal was tested by 2 questions in the questionnaire, i.e. whether any test can substitute amniocentesis with karyotyping and what they are. Despite the fact that the questionnaires were filled by women referred on the basis of abnormal screening tests, older age, or family/medical predisposition as stated above, $57.6 \%$ of patients did not know whether amniocentesis with karyotyping can be fully replaced by another test, and $11.4 \%$ of women thought it could be fully substituted by a different test. An ultrasound examination was identified as an alternative test by 17 patients in this last group, other screening tests by 9 women, chorionic villus sampling biopsy by one patient (medic herself), and one patient did not know.

Patients' compliance to undergo tests is boosted by their confidence in the test. Table 5 summarises levels of patient confidence for the combined first trimester screening test, biochemical second trimester screening test and karyotyping following amniocentesis.

Table 5. Confidence of patients in individual screening tests (\% of answers).

\begin{tabular}{lccc}
\hline & $\begin{array}{l}\text { Combined } \\
\text { first trimester } \\
\text { screening test }\end{array}$ & $\begin{array}{l}\text { Biochemical } \\
\text { second } \\
\text { trimester } \\
\text { screening test }\end{array}$ & $\begin{array}{l}\text { Amniocentesis } \\
\text { with } \\
\text { karyotyping }\end{array}$ \\
\hline Confident & 25.6 & 22.0 & 41.3 \\
$\begin{array}{l}\text { Mostly } \\
\text { confident }\end{array}$ & 63.1 & 62.0 & 42.4 \\
Not sure & 10.5 & 11.4 & 14.9 \\
$\begin{array}{l}\text { Mostly not } \\
\text { confident }\end{array}$ & 0.8 & 2.3 & 0.7 \\
Not confident & 0 & 2.3 & 0.7 \\
\hline
\end{tabular}

As stated above, one of the aims of this research was to test several hypotheses. We set 6 hypotheses in total and succeeded in proving some of them but failed to get 
conclusive results for others. Our results were generated by the STATISTICA programme:

H1: Knowing more information concerning individual tests reassures pregnant patients.

The correlation between these parameters was investigated using correlation analysis based on Pearson's correlation coefficient. The correlation coefficient was 0.235 , which is indicative of a correlation between the two variables. Despite the relatively weak strength of this correlation it is still possible to conclude that more relevant information reassures pregnant women.

$\mathrm{H} 2$ : Women referred for genetic consultation on the basis of abnormal first trimester screening test are more anxious and show more negative feelings than women referred on the basis of abnormal biochemical screening test of the second trimester, or due to older age.

A Chi-square test was not significant. The value was 0.386 .

H3: There is a correlation between previous spontaneous abortion(s) and negative feelings about amniocentesis.

A Chi-square test was significant. The value was 4.347, using $P<0.05$ and 1 degree of freedom. The critical value was 3.841 and we therefore accept the correlation.

H4: Women who discussed abnormal screening test results with their gynaecologist were less anxious than those seeking information on the internet.

This relationship was analysed using Pearson's correlation coefficient. This was 0.750 , which is indicative of a significant and relatively strong correlation between these variables. This correlation confirms that women informed by their gynaecologist have less negative feelings than those who seek help over the internet.

H5: There is a dependence between the decision with regards to going ahead with the amniocentesis and results of the screening test.

A Chi-square test was insignificant. The value was 0.664 , using $P<0.05$. There was no dependence.

\section{DISCUSSION}

The decision whether to undergo an invasive prenatal test following an abnormal screening test, or family or medical predisposition can have a significant impact on a woman's pregnancy as well as her future life and that of the whole family. To make the right decision the woman and her partner require relevant information presented in a way they can understand. A patient's gynaecologist should play a key role in conveying such information ${ }^{24}$.

Studies investigating the level of women's knowledge of prenatal tests started to appear in literature in the nineties $^{1}$. However, they mostly concentrate on screening programmes. Chilaka et al. ${ }^{2}$ investigated what British women knew about Down's syndrome using questionnaires, and found that only $33 \%$ of patients responded correctly. The authors also proved that the level of awareness was influenced by the presence of a disabled child in a woman's neighbourhood/social circle. It was also interesting that despite prior information about the test, only $48 \%$ of women knew that they had undergone a screening test for Down's syndrome. In the study of Stefansdottir et al. ${ }^{4}$, $57 \%$ of women reported to have sufficient information to make the right decision whether to undergo a screening test for Down's syndrome. Similar conclusions were reached by Mulley and Wallace ${ }^{3}$, Comerford et al..$^{25}$ and Dahl et al. ${ }^{5,26}$. Compared to studies related to screening programmes, there are significantly fewer published studies on patient awareness, decision making, and the need for support before amniocentesis ${ }^{6,7,10,27-30}$. These studies agree on the insufficient knowledge of women regarding amniocentesis; their expectations related to this test are often unrealistic ${ }^{31}$. Our conclusions are in agreement with the above findings. We found inadequate responses to even basic questions about women's knowledge of the test. Although $86.7 \%$ of women claimed to have sufficient awareness about the possibilities of amniocentesis, only $34.7 \%$ of women responded correctly to factual questions about amniocentesis, $31.7 \%$ of patients could not answer at all, and $15.1 \%$ of patients thought that amniocentesis could investigate all genetic tests. These findings are supported by the fact that only $42.4 \%$ of women were provided with information by their doctors with regards to the test whilst $44.7 \%$ of women sought information on the internet, which often provides incorrect or misleading facts.

Dahl et al. ${ }^{5}$ showed correlation between higher level of patients' knowledge and their well-being, in contrast they did not prove a correlation between higher level of knowledge and anxiety concerning the health of the baby. Provision of adequate information about an abnormal test result can lessen the stress associated with a referral for a genetic consultation and possible subsequent amniocentesis and karyotyping. Referral for a genetic consultation was associated with negative feelings (sadness, anxiety, sorrow, hopelessness) in $56.1 \%$ of respondents. These negative feelings improved in only $27.7 \%$ of these patients in the period between finding out an abnormal result and genetic consultation, whilst there was no change of feelings in $60.9 \%$ of patients, and increased distress and worsening of feelings in $11.4 \%$ of women. Women with a previous spontaneous miscarriage showed more negative feelings about amniocentesis testing. Other studies ${ }^{32,33}$ also confirmed increased levels of stress and anxiety during this period. Tercyak et al. ${ }^{6}$ showed the level of anxiety was highest just before the consultation. Previous experience with prenatal diagnostic testing, increased the perceived risk of a birth anomaly, and favourable attitudes towards abortion were independently associated with increased pre-counselling anxiety. Kowalcek et al. ${ }^{7}$ described depressive mood of women before chorionic biopsy, amniocentesis or ultrasound tests. Brajenović-Milić et al. ${ }^{10}$ reported that women's stress was significantly different according to the indication for amniocentesis, and women 
Questionnaire distributed before the genetic consultation

Dear patient,

Here we present you with a questionnaire related to the examination that will follow. Answering the questions will take you only a couple of minutes. The results will be used to improve the quality of the consultation and for processing a Dissertation Thesis. The questionnaire is annonymous and all the data obtained will be used only for the above stated purposes. At the choice-questions, please, tick off your answer. For the multi-choice questions, you are free to choose more answers. Thank you for filling it in!

1. Your age............

2. Your highest education level achieved:

- Elementary

- Apprenticed

- High School with a Final School-Leaving Exam

- University degree

3. Your current occupation (if you are on maternity leave, state your previous occupation)

4. Your family status:

- Single, living with a partner

- Single, living alone or at parents' house

- Married

- Divorced

5. You live in a settlement of:

- up to 5000 inhabitants

- $5000-10000$ inhabitants

- $10000-50000$ inhabitants

- $50000-100000$ inhabitants

- 100000 and more

6. Are you religious? Yes No

7. How many hours a day do you spend on the internet?

- Less than an hour

- 1-2 hrs

- 2 hrs and more

8. Is this:

- A spontaneus pregnancy?

- An In vitro fertilization?

9. And is this pregnancy

- Planned

- Unintended

10. How many time have you already been pregnant? Please, write down the number of spontaneous miscarriages, extrauterine pregnancies, abortions and also inborn errors of development if any at your babies have been diagnosed.

This pregnancy is No ............

Number of children you have

Number of previous spontaneous miscarriages ............

Number of demanded abortions

Inborn errors of development of your baby/fetus in your previous pregnancies ...........

11. Were there any inborn errors of development in your family relatives'? Yes No

12. If so, please, write down what kind of error was it and who had it (e.g. niece, sister, cousine from your father's side...)

13. Why have you been recommended for genetic counselling? Tick the correct answer.

- The screening results of the First trimester (blood taking and ultrasound check between the weeks 11-14)

- The results of the blood taking in the 16th week (called Triple Test)

- The combination of both these screenings

- Pregnancy at an older age

- Your personal or family medical history (including your partner's), state what precisely.

14. Do you know why we have to draw out the amniotic fluid (the amniocentesis procedure)?

- Yes

- To some extent

- I do not know

- A little

- No

15. What kind of diseases are revealed by amniocentesis?

16. Have you already gone through amniocentesis? Yes No

17. If you are well informed, where have you got the information from? (more answers are possible to be ticked off)
- The doctor/ gynecologist you currently visit

- The doctor you have visited for a special examination (e.g. the First trimester screening)

- Family or female-relatives who have already gone through this procedure

- Female friends, acquaintance

- Internet

- Specialized literature

- Other sources, name where exactly:

18. What did you feel when you were recommended for genetic counselling for of the above reasons?

You can tick more than one response.

- Anger

- Fear

- Anxiety

- Sadness

- Despair

- Nothing special, You just took it as a recommendation for another examination

- You were not surprised, You expected this

- You were glad to have as many examinations as possible to be sure your baby is healthy

- Other feelings and thoughts, write down

19. If you experienced a feeling of fear, anxiety or another negative feelings during the time of waiting for the genetical consultancy, these feelings have:

- Improved

- Got worse

- Remained the same

20. Have you been looking for anyone's support?

- Partner

- Parents

- Wider family

- Doctor

- Female friend(s)

- I haven't been looking for any support

- Other, write down

21. Have you decided to go through the amniotic fluid drawing (amniocentesis)?

Yes No I don't know

22. If you do, what is the reason for your decision?

23. If you do not, what is the reason for your decision?

24. Do You think the examination of the amniotic fluid can be substitued by another examination?

Yes No I don't know

25. If so, write down what type the substitutive check-up do you mean:

26. Do You have confidence in the results of amniocetesis?

- I definitely trust it

- I somewhat trust it

- I'm not sure

- I somewhat do not trust it

- I definitely do not trust it

The question No. 27 will be answered only by the women who have been recommended the genetic consultancy based on the results of the screening programmes (First and Second Trimester)

27. How much do you trust the results of the screening (blood taking and ultrasound)?

- I definitely trust it

- I somewhat trust it

- I'm not sure

- I somewhat do not trust it

- I definitely do not trust it

Thank You for filling in the questionnaire. Please, hand it in to a nurse or a doctor at the Dept.of Medical Genetics where your consultancy will take place. 
who underwent amniocentesis because of chromosomal aberration in previous pregnancy reported the highest stress score. Our findings were relatively surprising. We found no statistical differences between the feelings of women with abnormal first trimester screening test vs. those with abnormal second trimester screening test. This is despite the fact that the biochemical screening test of the second trimester is only $50-70 \%$ sensitive ( $5 \%$ false positivity), whilst the combined first trimester screening test is $95 \%$ sensitive $^{21}$. This finding can be explained by the insufficient level of our patients' knowledge. Due to small numbers available ( 2 patients), we were unable to compare these findings with those in patients with proven chromosomal aberrations in previous pregnancies.

Leithner et al. ${ }^{7}$, Hamilton et al. ${ }^{8}$, Rudnicki et al. ${ }^{34}$ and Borcherding et al. ${ }^{35}$ studied coping strategies of patients following an abnormal screening test result. Durand et al. ${ }^{29}$ pointed at the important supporting role of partners and doctors in the decision making process whether to undergo amniocentesis. In our cohort, 178 of 271 women sought support from their partner, 84 from their parents and only 15 from their doctors, whilst 69 patients did not find any support. These findings are supported by the fact that both partners experience stress events differently during pregnancy ${ }^{13,29}$.

We also investigated the level of a patients' confidence in individual screening tests and also in fetal karyotyping test. Our results showed that patients were significantly more confident about the combined first trimester screening test results. It was relatively surprising to find that the level of confidence in the combined first trimester screening was no different to that in the karyotyping test. We did not find any similar findings in the literature but our results could be a reflection in the low level of knowledge of women concerning individual tests. We also showed no statistical differences in the level of negative feelings between women who are referred following an abnormal first trimester versus second trimester screening test or on the basis of older age.

\section{CONCLUSION}

Our study showed that compared to international studies, Czech women show an insufficient level of knowledge in regards to pregnancy screening tests. Women confuse the possibilities of screening, invasive and ultrasound tests. Their expectations on invasive screening tests such as amniocentesis and subsequent karyotyping are unfounded. It is also important to note that doctors who take care of patients during pregnancy do not fulfil a sufficient role during stress situations. Referral for invasive tests during pregnancy is associated with largely negative feelings such as fear, anxiety, anger and hopelessness. Women's distress can be reduced if the information about indicated genetic consultation is conveyed correctly and can also help them make the right informed decision about their future course of action.

\section{Practice implication}

Our main recommendation, which is based on the findings of this study, would be to increase the level of women's knowledge of individual pregnancy screening tests. In addition to verbal communication, written information material and booklets would also be appropriate as patients and their partners can refer to them again. Gynaecologists should play a key role in this process.

\section{ACKNOWLEDGEMENT}

Conflict of interest statement: The author states that there are no conflicts of interest regarding the publication of this article.

\section{REFERENCES}

1. Smith DK, Shaw RW, Marteau, TM. Informed consent to undergo serum screening for Down's syndrome: the gap between policy and practice. BMJ 1994 24;309(6957):776.

2. Chilaka VN, Konje JC, Stewart CR, Taylor DJ. Knowledge of Down syndrome in pregnant women from different ethnic groups. Prenat Diagn 2001;21(3):159-64. doi:10.1002/10970223(200103)21:3<159::AID-PD20>3.0.CO;2-V

3. Mulvey S, Wallace EM. Women's knowledge of and attitudes to first and second trimester screening for Down's syndrome. Aust N Z J Obstet Gynaecol 2001;41(2):167-9. doi:10.1111/j.1471-0528.2000. tb11624.x

4. Stefansdottir V, Skirton $H$, Jonasson K, Hardardottir H, Jonsson JJ. Effects of knowledge, education, and experience on acceptance of first trimester screening for chromosomal anomalies. Acta Obstet Gynecol Scand 2010;89(7):931-8. doi:10.3109/00016341003686073

5. Dahl K, Hvidman L, Jørgensen FS, Kesmodel US. Knowledge of prenatal screening and psychological management of test decisions. Ultrasound Obstet Gynecol 2011;38(2): 152-7. doi:10.1002/uog.8856

6. Tercyak PK, Johnson SB, Roberts FR, Cruz AC. Psychological response to prenatal genetic counseling and amniocentesis. Patiens Education and Counselling 2001;43(1):73-84.

7. Kowalcek I, Mühlhof A, Bachmann S. Gembruch U. Depressive reactions and stress related to prenatal medicine procedures. Ultrasound Obstet Gynecol 2002;19(1):18-23. doi: 10.1046/j.09607692.2001.00551.x

8. Leithner K, Maar A, Fischer-Kern A, Hilger E, Löffler-Stastka H, Ponocny-Seliger E. Affective state of women following a prenatal diagnosis: predictors of a negative psychological outcome. Ultrasound Obstet Gynecol 2004;23(3):240-6. doi:10.1002/uog.978

9. Hamilton JG, Lobel M. Types, patterns, and predictors of coping with stress during pregnancy: Examination of the Revised Prenatal Coping Inventory in a diverse sample. J Psychosom Obstet Gynaecol 2008;29(2):97-104. doi:10.1080/01674820701690624.

10. Brajenović-Milić B, Dorčić, TM, Kuljanić K, Petrović O. Stress and Anxiety in Relation to Amniocentesis: Do Women Who Perceive Their Partners To Be More Involved in Pregnancy Feel Less Stressed and Anxious? Croat Med J 2010;51(2):137-43. doi: 10.3325/ cmj.2010.51.137

11. Doudová D, Calda P. Psychologické aspekty ukončení těhotenství pro vrozenou vadu. Moderní gynekologie a porodnictví [serial on the Internet]. 1996 [cited 2012 September 4];6(1):[about 3 p.]. Available from: http://www.levret.cz/texty/casopisy/mgp/obsahy/vol6c1/doudova.php

12. Peňazová J. Psychologické aspekty aminocentézy. Moderní gynekologie a porodnictví [serial on the Internet]. 1992 [cited 2012 September 4];2(2): [about 7 p.]. Available from: http://www.levret. cz/texty/casopisy/mgp/obsahy/vol2c2/penazova.php

13. Vágnerová M. Vývojová psychologie. Praha: Portál; 2000.

14. Takács L, Kodyšová E. Psychosociální faktory ovlivňující spokojenost rodiček s perinatální péčí. Česká gynekologie [serial on the Internet]. 2011 [cited 2012 September 8];76(3):199-204. Available from: http:// 
www.prolekare.cz/ceska-gynekologie-clanek/psychosocialni-faktory-ovlivnujici-spokojenost-rodicek-s-perinatalni-peci-35545

15. Ratislavová K, Beran J. Psychosociální intervence při porodu mrtvého plodu v historii a dnes. Česká gynekologie [serial on the Internet]. 2010 [cited 2012 September 8];75(5):462-6. Available from: http:// www.prolekare.cz/ceska-gynekologie-clanek/psychosocialni-intervence-pri-porodu-mrtveho-plodu-v-historii-a-dnes-33022

16. Tyrlík M, Jelínková J, Kukla L. Aspekty pozitivního prožívání těhotenství. Česká gynekologie [serial on the Internet]. 2004 [cited 2012 September 8];69(3):178-81. Available from: http://www.prolekare.cz/ceska-gynekologie-clanek/aspekty-pozitivniho-prozivanitehotenstvi-28310?search=tyrl\%C3\%ADk

17. Nicolaides $\mathrm{KH}$. UZ screening v $11 .-13^{+6}$. gestačním týdnu. Univerzita Palackého v Olomouci: Olomouc; 2004.

18. Snijders RJM, Johnson S, Sebire NJ, Noble PL, Nicolaide KH. First-trimester ultrasound screening for chromosomal defects. Ultrasound Obstet Gynecol 1996;7(3):216-26. doi:10.1046/j.14690705.1996.07030216.x

19. Johnson SP, Sebire NJ, Snijders JM, Tunkel S Nicolaides KH. Ultrasound screening for anencephaly at 10-14 weeks of gestation. Ultrasound Obstet Gynecol 1997;9(1):14-6. doi:10.1046/j.14690705.1997.09010014.x

20. Sherod C, Sebire NJ, Soares W, Snijders JM, Nicolaides, KH. Prenatal diagnosis of trisomy 18 at the 10-14-week ultrasound scan. Ultrasound Obstet Gynecol 1997;10(6):387-90. doi:10.1046/j.14690705.1997.10060387.x

21. Nicolaides $\mathrm{KH}$, Heath $\mathrm{V}$, Cicero S. Increased fetal nuchal translucency at 11-14 weeks. Prenat Diagn 2002;22(4):308-15. doi:10.1002/pd.308

22. Hájek Z, Kulovaný E, Macek M. Základy prenatální diagnostiky. Praha: Grada Publishing; 2000.

23. Ferjenčík J. Úvod do metodologie psychologického výzkumu. Praha: Portál; 2000

24. Nagle C, Lewis S, Meiser B, Gunn J, Halliday J, Bell R. Exploring general practitioners' experience of informing women about prenata screening tests for foetal abnormalities: A qualitative focus group study. BMC Health Serv Res 2008;8:114. doi:10.1186/1472-6963-8114.

25. Comerford FM, DeVore N, Valentine-Adams N, Bombard A, Merkatr IR. Informed consent for maternal serum alpha-fetoprotein screen- ing in an inner city population: How informed is it? J Obstet Gynecol Neonatal Nurs 1998;27(1):99-106. doi:10.1111/j.1552-6909.1998. tb02597.x

26. Dahl K, Kesmodel U, Hvidman L, Olesen F. Informed consent: attitudes, knowledge and information concerning prenatal examination. Acta Obstet et Gynecol Scand 2006;85(12):1414-9. doi:10.1080/00016340600985164

27. Green JM, Hewison J, Bekker HL, Brzant LD, Cuckle HS. Psychosocia aspects of genetic screening of pregnant women and newborns: a systematic review. Health Technol Assess 2004;8(33):iii,ix-x,1-109.

28. Ferber A, Onyeije Cl, Zepol CM, O`Reilly-Green C, Divon, MY. Maternal pain and anxiety in genetic amniocentesis: expectation versus reality. Ultrasound Obstet Gynecol. 2002;19(1):13-7. doi:10.1046/j.09607692.2001.00606.x

29. Durand MA, Stiel M, Boivin J, Elwyn G. Information and decision support needs of parents consideringamniocentesis: interviews with pregnant women and health professionals. Health Expect 2010;13(2):125-38. doi:10.1111/j.1369-7625.2009.00544.x.

30. Browner $\mathrm{CH}$, Preloran HM, Cox SJ. Ethnicity, bioethics, and prenatal diagnosis: the amniocentesis decisions of Mexican-origin women and their partners. Am J Public Health 1999;89(11):1658-66.

31. Marteau TM. Prenatal testing: towards realistic expectations of patients, providers and policy makers. Ultrasound Obstet Gynecol 2002;19(1):5-6. doi:10.1046/j.0960-7692.2001.00619.x

32. Abuelo DN, Hopmann MR, Barsel-Bowers G, Goldstein A. Anxiety in women with low maternal serum alpha-fetoprotein screening results. Prenat Diagn 1991;11(6):381-5.

33. Marteau TM, Cook R, Kidd J, Michie S, Johnson M, Slack J, Shaw RW. The psychological effects of false-positive results in prenatal screening for fetal abnormality: a prospective study. Prenat Diagn 1992;12(3):205-14.

34. Rudnicki SR, Graham JL, Habbousche DF, Ross RD. Social support and avoidant coping: correlates of depressed mood during pregnancy in minority women. Women Health 2001;34(3):19-34

35. Borcherding KE. Coping in Healthy Primigravidae Pregnant Women. J Obstet Gynecol Neonatal Nurs 2009;38(4):453-62. doi:10.1111/ j.1552-6909.2009.01041.x 